\title{
Job and Life Satisfaction of Teachers and the Conflicts They Experience at Work and at Home
}

\author{
Gürcü Erdamar ${ }^{1}$, Hüsne Demirel ${ }^{2}$ \\ ${ }^{1}$ Faculty of Education, Gazi University, Ankara, Turkey \\ ${ }^{2}$ Faculty of Tourism, Gazi University, Ankara, Turkey \\ Correspondence: Gürcü Erdamar, Faculty of Education, Gazi University, 06500, Ankara, Turkey.
}

Received: February 23, 2016 Accepted: March 14, 2016 Online Published: March 29, 2016

doi:10.11114/jets.v4i6.1502 URL: http://dx.doi.org/10.11114/jets.v4i6.1502

\begin{abstract}
This study aimed to find out job and life satisfaction and work-family and family-work conflict levels of teachers. The population of the study consisted of teachers who work in public and private preschools, primary, secondary, and high schools in Ankara. The sampling of the study was a total of 406 teachers-37 preschool, 126 primary school, 89 secondary school, and 154 high school teachers. The data for the study were collected through three different scales; Minnesota Job Satisfaction Scale, Life Satisfaction Scale, and Work-Family and Family-Work Conflicts Scale. According to the results of the study, job satisfaction average of teachers is good and life satisfaction average is moderate. Life satisfaction increases as job satisfaction increases. The results also suggest that teachers suffer more from work-family conflict than from family-work conflict. A negative and significant correlation has been found between job satisfaction and work-family conflict and also family-work conflict. According to the results of the hierarchic regression analysis, the variables that best predict job satisfaction are life satisfaction and work-family conflict.
\end{abstract}

Keywords: teacher, job satisfaction, life satisfaction, work-family conflict, family-work conflict

\section{Introduction}

Teaching is a profession which should be chosen not out of coincidence or obligation but out of passion. A teacher who loves and enjoys teaching will have a high level of job satisfaction. When a person is satisfied with what he or she does, he or she would be happy and productive in the workplace, where he or she spends most of his day, and this would contribute positively to his/her overall life satisfaction. A person who does not love or is not satisfied with what he/she does can be said to be unproductive in the workplace and unhappy in his daily life.

Job satisfaction is a multidimensional concept and has been defined in various ways by different researchers. To some researchers, job satisfaction is about a person's enjoying what he/she does (Dunnette, 1970); to some, it is about how a person feels about what he/she does (Balc1, 1985; Kaynak, 1990); to some, it is about motivation and overall satisfaction as a result of what the person does (Başaran, 1982; Eren, 1989), and to some others it is a total of positive and negative feelings of a person towards his/her job (Newstrom, 1986). In brief, job satisfaction is individuals' being satisfied with what they do, their being successful at what they do and feeling happy in general.

Job satisfaction is affected by various factors: Some of these factors are individual factors such as age, gender, work experience, occupation, level of education, and personality and some are environmental factors such as pay, promotion opportunities, working conditions, the nature of the work, and the employing institution (Ingersoll, 2001; Liu, 2007). A teacher's job satisfaction is affected by heavy workload, student behavior, parent-teacher relationships, relationships with colleagues and other co-workers, and the attitude of the school principal (Skaalvik \& Skaalvik, 2007; Van Houtte, 2006). Individuals who spend almost $70 \%$ of their day in the workplace should have job satisfaction because an individual's satisfaction with what he/she does will result in a positive attitude towards his/her job and an increased level of performance in the workplace (Erdoğan, 1997: Fitzgerald, 1972). In order to make the best of labor force, it should be ensured that individuals get enough job satisfaction and are employed in accordance with their talents and personal traits.

Job satisfaction is critical in a person's life; when a person gets enough job satisfaction, he/she will enjoy life in general, 
will be psychologically healthy and will have a great potential to increase his/her success both in professional and personal life. In other words, if one is satisfied with his/her job, he/she is also satisfied with his/her life. Therefore, it is highly important that teachers, as well as other professionals, do their job with enthusiasm and passion in order to make education system work effectively. A satisfied teacher is more willing to make time and energy for his/her students and for teaching (Bogler, 2001). In today's Turkey, however, teachers are facing a lot of problems (insufficient pay, organizational environment, management, and so on) regarding their professions and the problems they are facing contribute negatively to their professional performance, personal development, and their job and life satisfaction (Güver, 2004).

One of the factors that have a high impact on job satisfaction is overall life satisfaction. Life satisfaction includes an individual's expectations from life and the extent to which these expectations are met (Avşaroğlu, Deniz and Kahraman, 2005). The concept of life satisfaction, which was first coined by Neugarten in 1961, is the outcome or condition which occurs as a result of a comparison between what a person wants to have and what he/she actually has (Akt., Özer and Karabulut, 2003). To most people, life satisfaction is the ultimate goal in life. When a person's happy and positive feelings in his everyday life outweighs his negative feelings, it contributes positively to his life satisfaction. Life satisfaction is about a person's positive feelings towards his life as a whole (Mustafayeva and Bayraktaroğlu, 2014). According to Aysan and Bozkurt (2004), life satisfaction is the degree to which a person reaches the goals he sets for himself. Considering the fact that one of the goals of a person is to be good at what he does, life satisfaction and job satisfaction are inevitably correlated.

Research has also shown that there is a significant correlation between job satisfaction and life satisfaction (Avşaroğlu, Deniz and Kahraman, 2005; Bonebright, Clay and Ankenman, 2000; Keser, 2005; Lent and Brown, 2006; Perrone, Webb and Jackson, 2007). Now that job satisfaction has a high impact on life satisfaction, increasing job satisfaction levels of teachers will also increase their overall life satisfaction. In other words, life satisfaction and job satisfaction in this case will go hand in hand. Individuals who are not satisfied with their jobs will be unhappy in their personal lives also or the individual's leading an unhappy life will prevent him from having job satisfaction (Uyargil, 1983: 87).

Another factor that affects job and life satisfaction is family-work conflict (when family life affects work) or work-family conflict (when work affects family life). Sometimes what happens in the workplace might affect family life and sometimes problems in the family might affect work life negatively. A teacher's not being able to spare enough time for his family and home due to such reasons as taking work home (lesson planning, preparing exams, or grading exam papers) or having a heavy workload might lead to work-family conflict. Or, a female teacher's having to push work into the background due to household chores or child care might lead to family-work conflict.

Life at home and life at work are two important areas that reciprocally influence one another. Research has shown that an individual's work life is influenced by familial variables (such as the number of kids, age, and the support of the spouse) (Carlson \& Kacmar, 2000; Grzywacz \& Marks, 2000) and also one's family life is influenced by job necessities (Greenhaus and Beutell, 1985; Kossek and Özeki, 1998). Studies on work-family and family work conflicts have also suggested that family and work are mutually related (Adams, King, \& King, 1996; Frone and Cooper, 1992; Frone, Russell, \& Cooper, 1997; Hammer, Bauer, \& Grandey, 2003; Namasivayam \& Zhao, 2007; Trachtenberg, Anderson, \& Sabatelli, 2009). Work might interfere with family and vice versa. When work-related problems affect family life work-life conflict occurs, and when family-related problems affect work family-work conflict takes place. Both types of conflicts create negative consequences for both family and work life. For example, while work-family conflict decreases job satisfaction, family-work conflict decreases marriage satisfaction (Allen, Herst, Burck, \& Sutton, 2000; Frone, Russell and Cooper, 1992; Greenhouse, Collins \& Shaw, 2003; Noor, 2002). Teachers' low or high level of job and life satisfaction or conflicts at work and at home would directly affect the quality of education they give.

A lot of national and international studies have been done on teacher job satisfaction (Çermik, 2001; Dinham \& Scott, 2000; Köktürk, 1997; Filiz, 2014). These studies have generally focused on topics such as job satisfaction, individual and environmental factors affecting job satisfaction, and the correlation between job satisfaction and life satisfaction. However, the number of studies that focus on teachers' job and life satisfaction, and the relationships between family-work conflict and work-family conflict which affect their job and life satisfaction is rather limited, which was the main motivation for the present study.

The aim of this study is to determine the job satisfaction, overall life satisfaction, and work-family and family-work conflicts of teachers of various grade levels and the correlations among these variables. To that end, this study had the following sub-aims:

1. To determine teachers' job and life satisfaction levels and the levels of their family-work and work family conflicts.

2. To determine whether or not teachers' job satisfaction, life satisfaction and work-family/family-work conflicts change according to the type of the institution they work for, the level they are teaching, their gender, branch, marital status, 
length of service, and age.

3. To determine the relationships among variables such as teachers' job satisfaction, life satisfaction, and family-work/work-family conflicts.

4. To determine the variables that predicts teachers' job satisfaction levels.

\section{Method}

\subsection{Participants}

The population of the study consisted of teachers, who were chosen on a voluntary basis and were working in private and state-run preschools, primary, secondary, and high schools in Ankara in the 2012-2013 academic year. The study was limited to Altındağ, Çankaya, Keçiören and Yenimahalle Districts in Ankara. From these districts 9 preschools (2 private, 3 independent preschools, and 4 preschools affiliated with primary schools), 6 primary schools ( 2 private and 4 state-run schools), 4 secondary schools ( 2 private and 2 state-run schools), and 7 high schools ( 3 private and 4 state-run schools) were randomly selected.

406 teachers working in these schools voluntarily accepted to participate in the study. So, the sampling of the study consisted of 37 preschool, 126 primary school, 84 secondary school, and 154 high school teachers. Regarding the demographic features of these teachers, most of them are female (70.7\%) and married (75.9\%); approximately one quarter of the teachers fall into 30 and below age group (22.4\%), and 25.9\% have been married for 11-20 years. A great majority of the teachers work in public schools (83.0\%); 37.9\% work in high schools, $31.0 \%$ in primary schools, and almost half of the teachers $(43.3 \%)$ are classroom teachers.

\subsection{Data Collection Instruments}

Minnesota Job Satisfaction Scale was used in order to determine job satisfaction levels, and Life Satisfaction Scale was used to determine life satisfaction levels of teachers. Another scale was designed by the researchers to determine work-family and family-work conflicts of teachers.

\subsubsection{Minnesota Job Satisfaction Scale}

Minnesota Job Satisfaction Scale is a 5-item Likert scale of 20 questions, which was originally developed by Weiss, David, England and Lofguist in 1967 in order to determine job satisfaction. It was adapted to Turkish by Oran (1989). Each question has 5 options about how much an individual enjoys what he/she does (ranging from 1 I'm not satisfied at all to 5 I'm highly satisfied). I'm not satisfied at all is 1 point, I'm not satisfied is 2 points, I'm not sure how satisfied I am 3 points, I'm satisfied 4 points, and I'm highly satisfied is 5 points (Özday1, 1990). While analyzing the scale data the points are added up. The maximum points one can get is 100 , and the minimum is 20 . The closer the points are to 20 , the lesser the satisfaction is, and the closer the points are to 100, the higher the satisfaction is. In some of the studies the Cronbach-Alpha inner validity coefficient of the scale was found to be .90 and 0.89 (Yıldırım, 1996; Demirel and Koç Erdamar, 2009).

\subsubsection{Life Satisfaction Scale}

Life Satisfaction Scale, which was developed by Deiner, Larsen, Emmons and Griffin (1985), was translated and adapted into Turkish by Köker (1991). The scale consists of 5 statements. The maximum point one can get out of the scale is 25, and minimum is 5. A low score indicates low life satisfaction (Demirel and Canat, 2004). As for the reliability of the scale, test-retest reliability was $\mathrm{r}=.85$, item-test correlations are estimated to be between .71 and .80 (Avşaroğlu, Deniz and Kahraman, 2005).

\subsubsection{Work-family and Family-work Conflicts Scale}

The data for the study were collected via a scale developed by the researchers. Below is a thorough explanation of how the scale was developed and how the validity and reliability of the scale were assessed.

The Writing of the Statements in the Scale and Preliminary Analysis

First of all, 9 open-ended statements were written for the work-family and family-work conflicts scale. These statements included the problems teachers face in work and family life and whether or not the problems at work affect family life and the problems in the family affect work life. 30 teachers working in preschools, primary, and secondary schools were consulted during the process. The suggestions and opinions of these teachers were analyzed and 31 close-ended questions were prepared accordingly. The written statements were first given to 5 experts in the field to be analyzed in terms of the scope, clarity, statement similarities and then the necessary changes were done and the number of statements was reduced to 24 .

The Preparation of the Pilot Form of the Scale and Piloting 
In the pilot form, which consisted of 24 items, how the problems teachers face in their work and family life affect one another was inquired. In the preparation stage of the pilot form, rating totals and scaling approach (Likert scale) was taken into consideration. In this regard, the scaling included five options as Never (1), Rarely (2), Sometimes (3), Often (4), and Always (5). The scale was given to 316 teachers, considering gender, age group, length of service, marital status, type of institution (private or public), level of institution (primary, secondary, or high school), and branch.

The Processing and Analysis of the Data Collected from the Pilot Study

All of the statements in the scale are negative statements. Therefore, a high score on the scale indicates high family-work and work-family conflicts. In order to determine the items to be included in the final version of the scale, two different item analysis methods were used: item-scale correlation and lower-upper group differences. The validity of the final scale was tested through "construct validity" method. As for the reliability of the scale, the internal reliability of the scale was tested through Cronbach Alpha reliability coefficient.

According to item analysis based on item-scale correlation, the correlation coefficients between the score of each item and the score of the scale change between $0.47(\mathrm{~m} 12)$ and $0.74(\mathrm{~m} 6)$ and all the coefficients obtained are statistically significant at a level of 0.01 . The means of the scores of the answers provided by the respondents in the lower and upper groups differ statistically significantly for all items at a level of 0.01 .

The Validity and Reliability of the Scale

In order to prove the internal consistency of the scale, factor analysis and varimax upright rotation methods were used. With this aim in mind, firstly the suitability of the data for factor analysis was tested through Kaiser-Meyer Olkin (KMO) coefficient and Bartlett test. For the given data, the KMO value was found to be .90 . The chi-square value estimated in the Bartlett test was found to be significant (chi-square $(\mathrm{N}=316, \mathrm{sd}=190)$. $\mathrm{p}<.01)$. When KMO value is higher than .70 and Bartlett test turns out to be significant, it means that factor analysis can be done (Büyüköztürk, 2007).

For the 20 items included in the pilot study, factor analysis and varimax rotation method were used. The results of this analysis showed that the scale had two factors. 4 items, which had a factor load lower than .40, were removed from the scale. Thus, the first 9 items in the scale are about work-family conflict, and the $10^{\text {th }}$ to $20^{\text {th }}$ items are about family-work conflict. The total variance explained by the two factors is 53.679. The statements included in the first factor are about work-family conflict, so the first factor is titled as "work-family conflict". The work-family factor consists of 9 items. The variance explained by this factor, which has factor loads ranging from 0.843 and 0.628 , is 37.806 . With respect to the statements included in the second factor, all of them are about family-work conflict. Therefore, the second factor is titled as "family-work conflict". Here, there are 11 items which have factor loads changing between 0.772 and 0.568 . The variance explained by this factor is 15.873 . The Cronbach $\alpha$ internal consistency coefficient of the scale is 0,90 for the first factor, 0,89 for the second, and 0.90 for the whole scale.

A high score on the scale indicates a high level of conflict in the family and the workplace. The highest score one can get from work-family conflict is 45 , and from the family-work conflict 55 .

\subsection{Data Collection}

In order to determine job satisfaction levels of the teachers Minnesota Job Satisfaction Scale was used; to determine their life satisfaction levels Life Satisfaction Scale was used and to find about work-family and family-work conflicts Work-family Conflict Scale, which was developed by the researchers, was used. The scales were conducted by the researchers themselves.

\subsection{Data Analysis}

The mean and standard deviation of the scores the respondents received from the job satisfaction, overall life satisfaction, and work-family/family-work conflicts scales were calculated; also, in order to determine the effects of the respondents' demographic features on their job satisfaction, overall life satisfaction, and work-family/family-work conflicts, t-test and one-way variance analysis were used. When the results of the one-way variance analysis turned out to be statistically significant, Scheffe test was used in order to determine which groups differ from one another.

Whether or not there is a correlation among job satisfaction, overall life satisfaction, and work-family/family-work conflict variables is tested through Pearson Product-Moment Correlation Coefficient technique. Moreover, in order to determine which variables predict the teachers' job satisfaction levels, hierarchic regression analysis was done. The analysis was done by taking the demographic features as the $1^{\text {st }}$, job satisfaction as the $2^{\text {nd }}$, conflicts faced in the family and workplace as the $3^{\text {rd }}$ block. Since gender, level of institution, and branch were discrete variables, they are included in the analysis as "dummy variables". According to this, for gender variable, female teachers were coded as "1", and male teachers as" 0 ". For level of institution 3 dummy variables and for branch 5 dummy variables were formed. For level of institution, in Dummy 1 variable primary school teachers were coded as "1" and others as "0"; for Dummy 2 
variable, secondary school teachers were coded as "1" and others as "0"; for Dummy 3, high school teachers were coded as " 1 " and others as " 0 ". As for branch, for Dummy 1, preschool teachers were coded as " 1 "and others as "0"; for Dummy 2, classroom teachers were coded as " 1 " and others as "0"; for Dummy 3 variable, foreign language teachers were coded as " 1 " and others as "0"; for Dummy 4, social sciences teachers were coded as "1" and others as " 0 "; and for Dummy 5, science and mathematics teachers were coded as " 1 " and others as " 0 ".

\section{Results}

The descriptive statistics about the teachers' job and life satisfaction, and work-family and family-work conflicts are given in Table 1.

Table 1. Descriptive statistics about the teachers' job and life satisfaction, and work-family and family-work conflicts $(\mathrm{N}: 406)$

\begin{tabular}{lrc}
\hline Scale & $\overline{\mathrm{X}}$ & $\mathrm{S}$ \\
\hline Job satisfaction & 71.58 & 11.11 \\
\hline Life satisfaction & 15.32 & 4.44 \\
\hline Work-family conflict & 26.25 & 7.64 \\
\hline Family-work conflict & 20.43 & 6.71 \\
\hline
\end{tabular}

The mean of job satisfaction scores of the teachers was found to be 71.58. Considering that the highest score one can get from job satisfaction is 100 and that job satisfaction rate increases as the score increases, the teachers can be said to have good deal of job satisfaction. The mean of life satisfaction scores of the teachers was found to be 15.32. Considering that the highest score one can get from this scale is 25 and that life satisfaction rate increases as the score increases, it is seen that life satisfaction of the teachers is slightly above average. In short, it was found that job satisfaction levels of the teachers were a little higher than their life satisfaction levels.

The mean of work-family conflict scores of the teachers was 26.25 , and of family- work conflict scores 20.43 . This means that the teachers suffer more from work-family conflict than family-work conflict. Thus, it might be suggested that the problems teachers have at work interferes with their life at home, which leads to more conflicts at home due to their job requirements.

Table 2. Comparison of job and life satisfaction of teachers according to some demographic features

\begin{tabular}{|c|c|c|c|c|c|c|c|c|c|c|c|}
\hline \multirow[t]{2}{*}{ Variables } & & \multicolumn{5}{|c|}{ Job Satisfaction } & \multicolumn{5}{|c|}{ Life Satisfaction } \\
\hline & & $\mathrm{N}$ & $\mathrm{X}$ & $\mathrm{S}$ & $\mathrm{t} / \mathrm{F}$ & $\mathrm{p}$ & $\mathrm{N}$ & $\mathrm{X}$ & $\mathbf{S}$ & $t / F$ & $\mathbf{p}$ \\
\hline \multirow[t]{2}{*}{ Gender } & Female & 287 & 71.09 & 11.56 & \multirow{3}{*}{1.966} & \multirow[b]{2}{*}{.162} & 287 & 15.87 & 4.40 & \multirow[b]{2}{*}{15.73} & \multirow[b]{2}{*}{$.001 * * *$} \\
\hline & Male & 119 & 72.79 & 9.86 & & & 119 & 13.98 & 4.26 & & \\
\hline \multirow{2}{*}{$\begin{array}{l}\text { Marital } \\
\text { Status }\end{array}$} & Married & 308 & 71.98 & 10.77 & & \multirow[b]{2}{*}{.203} & 308 & 15.53 & 4.49 & & \multirow[b]{2}{*}{.085} \\
\hline & Single & 98 & 70.34 & 12.08 & \multirow[t]{2}{*}{1.629} & & 98 & 14.64 & 4.24 & \multirow[t]{2}{*}{2.978} & \\
\hline \multirow{2}{*}{$\begin{array}{l}\text { Type of } \\
\text { Institution }\end{array}$} & Private & 69 & 68.88 & 14.58 & & \multirow[b]{2}{*}{$.027 *$} & 69 & 15.84 & 3.80 & & \multirow[b]{2}{*}{.282} \\
\hline & Public & 337 & 72.14 & 10.19 & \multirow[t]{2}{*}{4.957} & & 337 & 15.21 & 4.56 & \multirow[t]{2}{*}{1.161} & \\
\hline \multirow{4}{*}{$\begin{array}{l}\text { Level of } \\
\text { Institution }\end{array}$} & Preschool & 37 & 73.95 & 10.18 & & \multirow{4}{*}{$\begin{array}{l}.001 * \\
2-3, \\
3-4\end{array}$} & 37 & 15.35 & 5.14 & & \multirow{3}{*}{.050} \\
\hline & $\begin{array}{l}\text { Primary } \\
\text { School }\end{array}$ & 126 & 69.59 & 10.86 & \multirow[t]{3}{*}{5.751} & & 126 & 14.65 & 4.46 & \multirow[t]{2}{*}{2.624} & \\
\hline & $\begin{array}{l}\text { Secondary } \\
\text { School }\end{array}$ & 89 & 75.22 & 9.09 & & & 89 & 16.36 & 4.58 & & \\
\hline & High School & 154 & 70.53 & 12.05 & & & 154 & 15.25 & 4.08 & \multirow{9}{*}{1.924} & \multirow{9}{*}{.065} \\
\hline \multirow[t]{8}{*}{ Branch } & Preschool & 37 & 74.49 & 10.38 & \multirow{8}{*}{1.468} & \multirow{8}{*}{.177} & 37 & 15.70 & 4.99 & & \\
\hline & $\begin{array}{l}\text { Classroom } \\
\text { teacher }\end{array}$ & 97 & 70.19 & 10.62 & & & 97 & 14.65 & 4.50 & & \\
\hline & $\begin{array}{l}\text { Foreign } \\
\text { Language }\end{array}$ & 44 & 74.90 & 10.11 & & & 44 & 16.57 & 4.46 & & \\
\hline & Turkish & 39 & 71.48 & 12.06 & & & 39 & 15.30 & 4.22 & & \\
\hline & Science & 46 & 71.08 & 12.76 & & & 46 & 15.48 & 4.05 & & \\
\hline & Mathematic & 43 & 68.25 & 12.91 & & & 43 & 14.64 & 4.00 & & \\
\hline & $\begin{array}{l}\text { Social } \\
\text { Sciences }\end{array}$ & 38 & 70.58 & 9.34 & & & 38 & 16.47 & 4.72 & & \\
\hline & Other* & 62 & 73.06 & 10.01 & & & 62 & 14.87 & 4.36 & & \\
\hline \multirow[t]{6}{*}{ Age } & $\begin{array}{ll}30 & \text { and } \\
\text { below } & \\
\end{array}$ & 91 & 71.21 & 12.89 & \multirow[t]{6}{*}{1.764} & .105 & 91 & 14.60 & 3.80 & & \\
\hline & $31-35$ & 46 & 70.07 & 12.47 & & & 46 & 15.22 & 3.93 & 1.079 & .371 \\
\hline & $36-40$ & 66 & 71.48 & 11.18 & & & 66 & 15.21 & 4.87 & & \\
\hline & $41-45$ & 79 & 70.65 & 10.19 & & & 79 & 15.77 & 4.66 & & \\
\hline & $46-50$ & 67 & 69.59 & 10.83 & & & 67 & 15.19 & 4.60 & & \\
\hline & $\begin{array}{ll}51 & \text { and } \\
\text { above }\end{array}$ & 57 & 73.89 & 9.68 & & & 57 & 16.18 & 4.74 & & \\
\hline
\end{tabular}

*:This group consists of teachers of Physical Education, Visual Arts, Music, Drama, Technological Design, and Computer Studies. 
When the teachers' job satisfaction levels were compared according to some demographic features, it was seen that teachers who work in public institutions and in secondary schools had higher job satisfaction levels and this result was found to be statistically significant $(p<.05, p<.001)$. Another finding was that teachers' job satisfaction levels did not change according to gender, marital status, branch, and age ( $\mathrm{p}>.05)$. When the teachers' life satisfaction levels were compared according to some demographic features, it was found that life satisfaction levels of female teachers were higher than those of male teachers and the difference between the two groups was statistically significant $(\mathrm{p}<.001)$. It was also found that marital status, type of institution, level of institution, branch, and age did not have any effect on teachers' life satisfaction levels ( $\mathrm{p}>.05)$.

Table 3 presents information about whether or not the work-family and family-work conflicts that teachers have change according to some demographic features. The results have shown that the scores of work-family conflicts differ significantly at a level of .05 according to gender, level of institution, and branch. In other words, work-family conflict is more experienced by female teachers than male teachers, more by primary school teachers than other teachers, and more by classroom teachers than teachers of other branch (arts, music, physical education, information Technologies, and so on). As for family-work conflict, it differed significantly only according to type of institution variable at a level of .05. According to this finding, teachers who work in public institutions suffer more from family-work conflict than those who work in private institutions.

Table 3. Comparison of work-family conflicts of teachers according to some demographic features

\begin{tabular}{|c|c|c|c|c|c|c|c|c|c|c|c|}
\hline \multirow[t]{2}{*}{ Variables } & & \multicolumn{5}{|c|}{ Work-family Conflict } & \multicolumn{5}{|c|}{ Family-work Conflict } \\
\hline & & $\mathrm{N}$ & $\mathrm{X}$ & $\mathrm{S}$ & $\mathrm{t} / \mathrm{F}$ & $\mathrm{p}$ & $\mathrm{N}$ & $\mathrm{X}$ & $\mathrm{S}$ & $\mathbf{t} / \mathbf{F}$ & $\mathbf{p}$ \\
\hline \multirow[t]{2}{*}{ Gender } & Female & 287 & 27.02 & 7.81 & \multirow{2}{*}{10.02} & \multirow{2}{*}{$.002 * *$} & 287 & 20.56 & 6.59 & \multirow[b]{2}{*}{.657} & \multirow[b]{2}{*}{.418} \\
\hline & Male & 119 & 24.41 & 6.89 & & & 119 & 20.85 & 6.70 & & \\
\hline \multirow{2}{*}{$\begin{array}{l}\text { Marital } \\
\text { Status }\end{array}$} & Single & 69 & 27.77 & 9.49 & \multirow[b]{2}{*}{3.284} & \multirow[b]{2}{*}{.071 } & 308 & 20.59 & 6.44 & \multirow[b]{2}{*}{.773} & \multirow[b]{2}{*}{.380} \\
\hline & Married & 337 & 25.94 & 7.18 & & & 98 & 19.71 & 7.51 & & \\
\hline \multirow{2}{*}{$\begin{array}{l}\text { Type of } \\
\text { Institution }\end{array}$} & Public & 308 & 15.53 & 4.49 & \multirow[t]{2}{*}{2.978} & \multirow[t]{2}{*}{.085} & 337 & 20.82 & 6.67 & \multirow[b]{2}{*}{6.825} & \multirow[b]{2}{*}{$.009^{*}$} \\
\hline & Private & 98 & 14.64 & 4.24 & & & 69 & 18.52 & 6.63 & & \\
\hline \multirow{4}{*}{$\begin{array}{l}\text { Level of } \\
\text { Institution }\end{array}$} & Preschool & 37 & 25.97 & 8.37 & \multirow{4}{*}{3.280} & \multirow{4}{*}{$\begin{array}{l}.021^{*} \\
2-3\end{array}$} & 37 & 20.67 & 6.17 & \multirow{3}{*}{1.504} & \multirow{3}{*}{.213} \\
\hline & $\begin{array}{l}\text { Primary } \\
\text { School }\end{array}$ & 126 & 27.93 & 7.64 & & & 126 & 20.94 & 7.04 & & \\
\hline & $\begin{array}{l}\text { Secondary } \\
\text { School } \\
\end{array}$ & 89 & 24.88 & 6.87 & & & 89 & 19.11 & 5.81 & & \\
\hline & High School & 154 & 25.74 & 7.71 & & & 154 & 20.71 & 6.99 & \multirow{9}{*}{1.717} & \multirow{9}{*}{.103} \\
\hline \multirow[t]{8}{*}{ Branch } & Preschool & 37 & 25.54 & 8.30 & \multirow{8}{*}{2.488} & \multirow{8}{*}{$\begin{array}{l}.016^{*} \\
2-8\end{array}$} & 37 & 20.54 & 6.30 & & \\
\hline & $\begin{array}{l}\text { Classroom } \\
\text { teacher }\end{array}$ & 97 & 28.18 & 7.36 & & & 97 & 21.52 & 7.32 & & \\
\hline & $\begin{array}{l}\text { Foreign } \\
\text { Language }\end{array}$ & 44 & 25.57 & 6.22 & & & 44 & 18.98 & 6.12 & & \\
\hline & Turkish & 39 & 28.26 & 7.92 & & & 39 & 21.54 & 7.36 & & \\
\hline & Science & 46 & 24.76 & 8.60 & & & 46 & 19.37 & 7.31 & & \\
\hline & Mathematic & 43 & 25.64 & 7.38 & & & 43 & 19.00 & 4.81 & & \\
\hline & $\begin{array}{l}\text { Social } \\
\text { Sciences } \\
\end{array}$ & 38 & 26.84 & 6.83 & & & 38 & 22.10 & 7.25 & & \\
\hline & Other & 62 & 24.04 & 7.65 & & & 62 & 19.71 & 5.87 & & \\
\hline \multirow[t]{6}{*}{ Age } & $\begin{array}{ll}30 & \text { and } \\
\text { below } & \\
\end{array}$ & 91 & 14.60 & 3.80 & \multirow{6}{*}{1.079} & & 91 & 21.40 & 7.63 & & \\
\hline & $31-35$ & 46 & 15.22 & 3.93 & & .371 & 46 & 20.15 & 6.15 & 2.082 & .067 \\
\hline & $36-40$ & 66 & 15.21 & 4.87 & & & 66 & 21.32 & 6.28 & & \\
\hline & $41-45$ & 79 & 15.77 & 4.66 & & & 79 & 20.49 & 6.04 & & \\
\hline & $46-50$ & 67 & 15.19 & 4.60 & & & 67 & 20.36 & 7.16 & & \\
\hline & $\begin{array}{ll}51 & \text { and } \\
\text { above }\end{array}$ & 57 & 16.18 & 4.74 & & & 57 & 18.04 & 6.02 & & \\
\hline
\end{tabular}

Table 4 presents results about the correlations among job satisfaction, life satisfaction, work-family conflict, and family-work conflict and Table 5 presents the results of the hierarchic regression analysis.

Table 4. Correlations between job and life satisfaction and work-family/family-work conflicts

\begin{tabular}{llll}
\hline & Life Satisfaction & $\begin{array}{l}\text { Work-Family } \\
\text { Conflict }\end{array}$ & $\begin{array}{l}\text { Family-Work } \\
\text { Conflict }\end{array}$ \\
\hline Job Satisfaction & $.281^{* *}$ & $-.375^{* *}$ & $-.198^{* *}$ \\
\hline Life Satisfaction & & $-.232^{* *}$ & $-.197^{* *}$ \\
\hline Work-Family Conflict & & $.435^{* *}$ \\
\hline
\end{tabular}


According to the results of the correlation analysis, there found to be a positive significant correlation ( $\mathrm{r}=.281$ ) between job satisfaction and life satisfaction. As job satisfaction increases, so does life satisfaction. A negative and significant correlation was found between job satisfaction and work-family conflict $(\mathrm{r}=-.375)$ and also between job satisfaction and family-work conflict $(\mathrm{r}=-.198)$, at a level of .001. The more the conflicts, the less job satisfaction is. A negative and significant correlation was found between the teachers' life satisfaction and work-family conflicts $(r=-.232)$ and also between life satisfaction and family-work conflicts $(\mathrm{r}=-.197)$, at a level of .001 . As life satisfaction increases, work-family and family-work conflicts decrease. Between work-family conflict and family-work conflict ( $\mathrm{r}=.435)$, there found to be a positive and significant correlation at a level of .001. This means that as work-family conflict increases, family-work conflict also increases.

Table 5. Results of the hierarchic regression analysis

\begin{tabular}{|c|c|c|c|c|}
\hline Block/Predictors & $\mathrm{B}$ & SHB & $\beta$ & $\Delta \mathrm{R}^{2}$ \\
\hline \multicolumn{5}{|l|}{ I. Demographic Features } \\
\hline Age & .18 & 0.38 & .022 & \multirow{10}{*}{$.079 * * *$} \\
\hline Gender & -1.690 & 1.199 & -.069 & \\
\hline Level of institution dummy1 & -1.131 & 7.418 & -.047 & \\
\hline Level of institution dummy 2 & 4.326 & 7.186 & .162 & \\
\hline Level of institution dummy3 & .465 & 7.212 & .020 & \\
\hline Branch dummy1 & 3.522 & 7.305 & .092 & \\
\hline Branch dummy2 & 1.953 & 2.329 & .075 & \\
\hline Branch dummy3 & 2.033 & 1.996 & .057 & \\
\hline Branch dummy4 & -.890 & 1.739 & -.032 & \\
\hline Branch dummy5 & -2.515 & 1.656 & -.094 & \\
\hline II. Life Satisfaction & .483 & .121 & $.193 * * *$ & $.146^{* * *}$ \\
\hline \multicolumn{5}{|l|}{ III. Work and Family Conflicts } \\
\hline Work-family conflict & -.424 & .076 & $-.292 * * *$ & \\
\hline Family-work conflict & -.039 & .084 & -.024 & $.224 * * *$ \\
\hline
\end{tabular}

According to the table, the demographic features of the teachers explain $7.9 \%$ of the variance related to job satisfaction (demographic features, $\mathrm{F}(10,393) 3.356, \mathrm{p}<.001)$. This suggests that demographic features have a significant effect on job satisfaction. Life satisfaction explains $14.6 \%$ of job satisfaction (job satisfaction, $F(11,392) 6.086, p<.001$ ). Compared to the demographic features, life satisfaction is more of a predictor for job satisfaction. Work-family and family-work conflict in the third block explain $22.4 \%$ of job satisfaction (conflicts experienced in the family and at work, $F(13,390) 8.666, p<.001)$. Especially the negative effect of the conflicts experienced in the workplace on the family life seems to be an important predictor of job satisfaction. There is a negative correlation between job satisfaction and both types of conflicts. Also, the negative effect of the conflicts experienced in the workplace on family life decreases the satisfaction one gets from his/her job. According to these results, we can conclude that life satisfaction and work-family conflict are two effective variables in predicting job satisfaction and that the effect of the demographic features is relatively lower.

\section{Discussion and Conclusion}

This study aimed to determine job satisfaction, life satisfaction, work-family conflict, and family-work conflict levels of teachers, to find out whether or not these variables differ according to certain demographic variables, and to determine the relationships among the variables.

The results of the study have shown that job satisfaction levels of teachers are above average. Life satisfaction mean of teachers is slightly above average - not significantly low. As for the conflicts teachers experience at work and at home, it is seen that teachers suffer more from work-family conflict than family-work conflict. The problems faced in the workplace cause additional problems such as job dissatisfaction, job stress, and lack of organizational commitment and they also influence one's life at home (Allen \& et.al, 2000). It might be speculated that teachers reflect more the problems they face at work on their family and experience more conflicts at home due to the requirements of their job. Previous studies have also reported that work-family conflict is more common than family-wok conflict (Anafarta, 2011; Geurts et al., 2005; Grzywacz \& Marks, 2000; Kinnunen et.al., 2004; Marais vd., 2009; Panatik et al., 2011). Individuals prefer to fulfill their job-related responsibilities at the expense of their responsibilities at home. A problem experienced at work affects a teacher's life at home negatively. A teacher's being tense and stressed due to a problem at work and dwelling on the problem when at home lower his/her quality of life at home.

The study has also investigated whether or not job and life satisfaction, work-family/family-work conflict levels of teachers differ according to certain demographic variables. According to the results, it has been found that job satisfaction levels of teachers do not change according to gender, marital status, branch, and age. Some earlier studies 
have found that job satisfaction increases as age and length of service increase (Günbay1 and Toprak, 2010; Koruklu et al., 2013), and some others have found, similar to the present study, that age, gender, marital status, and branch do not create much of a difference (Filiz, 2014; Telef, 2011).

Job satisfaction of teachers working in public schools is higher than that of those working in private schools and the difference between the two groups of teachers is statistically significant $(p<.05)$. Turkish schools are either public or private schools, all of which are affiliated with the Ministry of National Education. Teachers who work in public schools are permanent government officials and they do not have the risk to be made redundant. However, in private schools teachers work on contracts, which are renewed annually according to their performances. Therefore, teachers working in private schools need to work hard, be successful, and continually develop themselves so as to ensure that their contracts will be renewed for the following academic year. It might be the case that these factors affect teachers' job satisfaction levels negatively. Yılmaz and Şahin's (2009) study have also concluded that job satisfaction levels of teachers change according to type of institution. The present study has found that teachers working in secondary schools have higher levels of job satisfaction compared to teachers of other levels. Preschool teachers have also been found to have higher levels of job satisfaction, although the difference is not statistically significant. The reason why the job satisfaction levels of primary and high school teachers are lower might be student-related problems such as adaptation to school in the primary level and classroom management problems related to students' misbehavior due to adolescence in high schools. Other studies have also found that job satisfaction levels of high school teachers are lower compared to job satisfaction levels of other groups of teachers (Kılıç, Tanrıkulu and Uğur, 2013).

Of all the demographic features under concern, only gender has been found to be effective in teachers' life satisfaction $(\mathrm{p}<.001)$; other demographic features are found to be ineffective ( $p>05)$. Female teachers have higher levels of life satisfaction compared to male teachers.

One of the noteworthy findings concerning work-family and family-work conflicts is that female teachers suffer more from work-family conflict and male teachers more from family-work conflict, although the difference is not significant. Some other studies have also reported that female teachers have more conflicts than male teachers and that work-family conflict is more common than family-work conflict. (Anafarta, 2011; Ayo, Henry \& Adebukola, 2009; Geurts et al., 2005; Grzywacz \& Marks, 2000; Kinnunen et.al., 2004; Özmete and Eker, 2012; ). Such a finding might not be a surprise, considering the fact that women have more responsibilities at home (cooking, cleaning, child care, and so on) and, on top of that, that these responsibilities are seen among the basic duties of women. Another finding is that teachers working in public institutions experience family-work conflict more than those working in private institutions.

According to the result of the correlation analysis, there is a positive significant correlation $(\mathrm{r}=.281)$ between job satisfaction and life satisfaction. The same result has been found by some previous studies also (Bonebright, Clay \& Ankenman, 2001; Perrone, Webb \& Jackson, 2007). Since individuals spend most of their time at work and make their job the center of their lives, their job satisfaction influences their life satisfaction; therefore, one increases as the other increases.

A negative and significant correlation has been found between job satisfaction and work-family conflict $(\mathrm{r}=-.375)$ and also between job satisfaction and family-work satisfaction $(\mathrm{r}=-.198)$, at a level of .001 . In other words, as the conflicts at work and at home increase, job satisfaction decreases (Dursun and İştar, 2014; Özdevecioğlu and Doruk, 2009; Turunç and Erkuş, 2010). There is also a negative and significant correlation between teachers' life satisfaction and work-family conflicts $(r=-.232)$ and also between their life satisfaction and family-work conflicts $(r=-.197)$, at a level of .001. As life satisfaction increases, work-family and family-work conflicts decrease. Similar studies which have been conducted with teachers and academicians also report that there is a significant and negative correlation between life satisfaction and work-family conflict (Akın, 2008; Mustafayeva and Bayraktaroğlu, 2014; Özdevecioğlu and Doruk, 2009). Regarding the correlation between work-family conflict and family-work conflict, there seems to be a positive and significant correlation ( $\mathrm{r}=.435)$ between the two conflicts, at a level of .001 . It means that as work-family conflict increases, family-work conflict also increases. According to the results of the hierarchic regression analysis, the variables that best predict jobs satisfaction are life satisfaction and work-family conflict.

In conclusion, the present study, which has focused on job satisfaction, life satisfaction, work-family conflict and family-work conflict levels of teachers, has found that job satisfaction and life satisfaction are correlated and one increases as the other increases, and that as work-family conflict and family-work conflict increase, job satisfaction and life satisfaction decrease.

It is highly important for the future of our country that teachers, to whom we entrust our future and who contribute greatly to the development of our country, have high levels of job and life satisfaction. Therefore, it is critical that school administrators and politicians take the necessary steps to ensure this. When job satisfaction levels of teachers are high, their life satisfaction levels will also increase. 
Individual and organizational strategies are required in order to increase job and life satisfaction of teachers and to decrease the conflicts they have. Teachers need to learn how to cope with stress, to take good care of their physical and psychological health, and to be able to maintain their work-life balance. The conflicts that teachers have might be decreased if school administrators create a positive working environment, support teachers in solving the problems they face at work, and motivate them. Work-family conflict increases job dissatisfaction and job stress and decreases organizational commitment. On top of that, it leads to problems in the family. Increasing job and life satisfaction of teachers is of great importance in terms of decreasing the conflicts experienced at work and at home. Further studies are needed to reveal the causes of the conflicts teachers experience in the workplace and in the family.

\section{References}

Adams, A. G., King, L. A., \& King, D. W. (1996). Relationships of job and family involvement, family social support, and work-family conflict with job and life satisfaction. Journal of Applied Psychology, 4, 411-420. http://dx.doi.org/10.1037/0021-9010.81.4.11

Akın, M. (2008). Örgütsel destek, sosyal destek ve iş/aile çatışmalarının yaşam tatmini üzerindeki etkileri. [The effects of organizational support, social support and work/family conflicts on life satisfaction.] Erciyes Üniversitesi Sosyal Bilimler Enstitüsü Dergisi, 25(2), 141-170.

Allen, T. D., Herst, D., Brück, C. S., \& Sutton, M. (2000). Consequences associated with work-to-family conflict: a review and agenda for future research. Journal of Occupation Health Psychology, 5(2), 278-308. http://dx.doi.org/10.1037/1076-8998.5.2.278

Anafarta, N. (2011). The Relationship between work-family conflict and job satisfaction: A structural equation modeling (SEM) approach. International Journal of Business and Management, 6(4), 168-177. http://dx.doi.org/10.5539/ijbm.v6n4p168

Avşaroğlu, S., Deniz, M. E., \& Kahraman, A. (2005). Teknik öğretmenlerde yaşam doyumu iş doyumu ve mesleki tükenmişlik düzeylerinin incelenmesi. [Examining job satisfaction and life satisfaction and burnout in the vocational technical teacher.] Selçuk Üniversitesi Ĕ̈itim Fakültesi Dergisi, 14, 115-129.

Ayo, H. T., Henry, S., \& Adebukola, K. T. (2009). Psychosocial variables as predictors of work-family conflict among secondary school teachers in irele local government area, Ondo State, Nigeria. Pakistan Journal of Social Sciences, 6(1), 11-18. http://dx.doi.org/pjssci.2009.11.18

Aysan, F., \& Bozkurt, N. (2004). Okul psikolojik danışmanlarının yaşam doyumu, stresle başa çıkma stratejileri ve olumsuz otomatik düşünceleri. [School counselors of life satisfaction, stress, coping strategies and negative automatic thoughts.] İzmir ili örneklemi. XIII. Ulusal Eğitim Bilimleri Kurultayı, (6-9 Temmuz 2004), İnönü Üniversitesi, Malatya.

Balcı, A. (1985). Eğitim yöneticisinin iş doyumu. [The training manager job satisfaction.]Unpublished doctoral thesis, Ankara Üniversitesi, Ankara.

Başaran, İ. E. (1982). Örgütsel Davranış. [Organizational behavior.] Ankara: A.Ü.E.F. Yayınları.

Bogler, R. (2001). The influence of leadership style on teacher job satisfaction. Educational Administration Quarterly. 37(5), 662. http://dx.doi.org/10.1177/00131610121969460.

Bonebright, C. A., Clay, D. L., \& Ankenman, R. D. (2000). The relationship workaholdism with work-life conflict, life satisfaction, and purpose of life. Journal of Counseling psychology, 47(4), 469-477.

Büyüköztürk, Ş. (2007). Sosyal bilimler için veri analizi el kitabı. [Data analysis for social sciences.] Ankara: PegemA Yayıncilik.

Carlson, D. S., \& Kacmar, K. M. (2000). Work-family conflict in the organization: Do live role values make a differences? Journal of Management, 26 (5), 1031-1054. http://dx.doi.org/10.1177/014920630002600502.

Çermik, E. (2001). Ortaöğretim fizik öğretmenlerinin profili, iş tatmini ve motivasyonu. [Profile, work satisfaction and motivation of physics teachers in high schools.] Unpublished master thesis, Marmara Üniversitesi, İstanbul.

Demirel, H. \& Koç Erdamar, G. (2009). Examining the relationship between job satisfaction and family ties of Turkish primary school teachers. Procedia-Social and Behavioral Sciences, 1(1), 2211-2217. http://dx.doi.org/10.1016/j.sbspro.2009.01.389

Dinham, S., \& Scott, C. (2000). Moving into the third, outer domain of teacher satisfaction. Journal of Educational Administration, 38(4), 379-396. http://dx.doi.org/10.1108/09578230010373633

Dunnette, P. (1970). Psychology and industry. London: The Callier-McMillan Company. 
Dursun, S., \& İştar, E. (2014). Kadın Çalışanların Yaşamış Oldukları İş Aile Çatışmasının İş ve Yaşam Doyumu Üzerine etkisi. [Effects of work-family conflit of woman on job and life satısfaction.] atatürk Üniversitesi İktisadi ve İdari Bilimler Dergisi, 8(3), 127-137.

Erdoğan, İ. (1997). İşletmelerde davranış. [Behavior in businesses] İstanbul: İstanbul Üniversitesi İşletme Fakültesi Yayınlar1.

Eren, E. (1989). Yönetim psikolojisi. [Management psychology.] Genişletilmiş 3. Baskı, İstanbul: Yön Ajans.

Filiz, Z. (2014). Öğretmenlerin iş doyumu ve tükenmişlik düzeylerinin incelenmesi. [An analysis of the levels of job satisfaction and burnout of teachers.] Uluslar arası Yönetim, İktisat ve İşletme Dergisi. 10(23), 157-171.

Fitzgerald, S. M. (1972). A career development study of elementary school teachers: University of Minnesota.

Frone, M. R., \& Cooper, M. L. (1992). "Prevalence of work-family conflict: are work and family boundraies asymmetrically permeable?". Journal of Organizational Behavior, 13(7), 723-729. http://dx.doi.org/10.1002/job.4030130708

Frone, M. R., Russell, M., \& Cooper, M. L. (1992). Antecedents and outcomes of work-family conflict: Testing a model of the work-family interface. Journal of Applied Psychology, 77(1), 65-78.

Frone, M. R., Russell, M., \& Cooper, M. L. (1997). Relation of work-life conflict to health outcomes: A four-year longitudinal study of employed parents, Journal of Occupational and Organizational Psychology, 70(4), 325-335. http://dx.doi.org/10.1111/j.2044-8325.1997.tb00652.x

Geurts, S. A. E., Taris, T. W., Kompier, M. A. J., Dikkers, J. S. E., Van Hooff, M. L. M., \& Kinnunen, U. M. (2005). Work-home interaction from a work psychological perspective: Development and validation of a new questionnaire, the SWING. Work \& Stress, 19(4), 319-339. http://dx.doi.org/10.1080/02678370500410208

Greenhaus, J. H., \& Beutell, N. J. (1985). Sources of conflict between work and family roles, Academy of Management Review, 10, 76-88.

Greenhouse, J. H., Collins, K. M., \& Shaw, J. D. (2003). The relation between work- family bakance and quality of life. Journal of Vocational Behavior, 3(63), 510-531. http://dx.doi.org/10.1016/S0001-8791(02)00042-8

Grzywacz, J. G., \& Marks, N. F. (2000). Family, work, work-family spillover, and problem drinking during midlife. Journal of Marriage and the Family, 62(2), 336-348. http://dx.doi.org/10.1111/j.1741-3737.2000.00336.x

Günbayı, İ., \& Toprak, D. (2010). İlköğretim okulu sınıf ve özel sınıf öğretmenlerinin iş doyum düzeylerinin karşılaştırılması. [A comparison of primary school teachers and special primary school teachers' job satisfaction levels.] İlköğretim Online, 9(1), 150-169.

Hammer, L. B., Bauer, T. N., \& Grandey, A. A. (2003). Work-family conflict and workrelated withdrawal behaviors. Journal of Business and Psychology, 17(3), 419-436. http://dx.doi.org/10.1023/A:1022820609967

Ingersoll, R. M. (2001). Teacher turnover, teacher shortages, and organization of schools. University of Washington, Center for the Study of Teaching and Policy. http://depts.washington.edu/ctpmail/PDFs/Turnover-Ing-01-2001.pdf

Kaynak, T. (1990). Organizasyonlarda davranış. [Behaviour in organisations.] İstanbul: İstanbul Üniversitesi İşletme Fakültesi Yayınları.

Keser, A. (2005). Akademisyenlerin çalışan tatmini-yaşam tatmini araştırması. [Academics' job satisfaction-life satisfaction.] Ekonomi, Sosyoloji ve Politika Dergisi, 2, 1.

Kılıç, S., Tanrıkulu, T., \& Uğur, H. (2013). Devlet okullarında görev yapan öğretmenlerin iş doyumu ve sosyal karşılaştırma düzeylerinin incelenmesi. [Job satisfaction and social comparison levels of teachers working for state schools.], International Journal of Human Sciences, 10(1), 760-779.

Kinnunen, U., Geurts, S., \& Mauno, S. (2004). Work-to-family conflict and its relationship with satisfaction and well-being: A one-year longitudinal study on gender differences. Work ve Stress, 18(1), 1-22. http://dx.doi.org/10.1080/02678370410001682005

Köker, S. (1991). Normal ve Sorunlu ergenlerin yaşam doyumu düzeyinin karşılaştıılması. [A comparison of normal and troubled adolescent life satisfaction levels.] Unpublished master thesis, Ankara: Ankara Üniversitesi Sosyal Bilimler Enstitüsü.

Köktürk, T. (1997). İlköğretim okulları ikinci kademe İngilizce öğretmenlerinin profili, motivasyonu ve iş tatmini. [The profiles, motivation and job satisfaction of secondary school English teachers.] Unpublished master thesis. İstanbul: Marmara Üniversitesi. 
Koruklu, N., Feyzioğlu, B., Kiremit, H. Ö., \& Aladağ, E. (2013). Öğretmenlerin iş doyum düzeylerinin bazı değişkenlere göre incelenmesi. [Examining teachers job satisfaction level according to some variables.] Mehmet Akif Ersoy Üniversitesi Eğitim Fakültesi Dergisi, 13(25), 119-137.

Kossek, E. E., \& Ozeki, C. (1998). Work-family conflict, policies, and the job-life satisfaction relationship: a review and directions for organizational behavior-human resources research. Journal of Applied Psychology, 83(2), 139-149. http://dx.doi.org/10.1037/0021-9010.83.2.139

Lent, R. W., \& Brown, S. D. (2006). Integrating person and situation perspectives on work satisfaction: A social-cognitive view. Journal of Vocational Behavior, 69(2), 236-247. http://dx.doi.org/10.1016/j.jvb.2006.02.006

Liu, X. (2007). The effects of teacher influence at school on first-year teacher attrition: A multilevel analysis of the Schools and Staffing Survey for 1999-2000. Educational Research and Evaluation, 13(1), 1-16. http://dx.doi.org/10.1080/13803610600797615

Marais, C., Mostert, K., Geurts, S., \& Taris, T. (2009).The psychometric properties of a translated version of the Survey Work-Home Interaction - Nijmegen (SWING) instrument. South African Journal of Psychology, 39(2), 202-219. http://dx.doi.org/10.1177/008124630903900206.

Mustafayeva, L., \& Bayraktaroğlu, S. (2014). İş-Aile Çatışmaları ve Yaşam Tatmini Arasındaki İlişki: Türkiye ve İngiltere'deki Akademisyenlerin Karşılaştırılması. [The relatıonship between work-family conflict and life satisfaction: comparative study between the UK and Turkey.] Isşletme Bilimi Dergisi, 2(1), 127-145.

Namasivayam, K., \& Zhao, X. (2007). An investigation of the moderating effects of organizational commitment on the relationships between work-family conflict and job satisfaction among hospitality employees in India. Tourism Management, 28, 1212-1223. http://dx.doi.org/10.1016/j.tourman.2006.09.021

Newstrom, J. W. (1986). Human behavior at work. New York. McGraw-Hill.

Noor, N. M. (2002). Work-family conflict, locus of control, and women's well-being: Test of alternative pathways. Journal of Social Psychology, 142(5), 645-662. http://dx.doi.org/10.1080/00224540209603924

Oran, N. B. (1989). Job Satisfaction of a Group of Academical Staff in Marmara University. Unpublished master thesis, Marmara Üniversitesi Sosyal Bilimler Enstitüsü, İstanbul.

Özdayı, N. (1990). Resmi ve özel liselerde çalışan öğretmenlerin iş tatmini ve iş streslerinin karşılaştırmalı analizleri. [The comparison of job satisfaction and job stress of teachers who work in public and private high schools Unpublished doctoral thesis. İstanbul: İstanbul Üniversitesi İşletme Fakültesi.

Özdevecioğlu, M., \& Doruk, N. Ç. (2009) Organizasyonlarda İş-Aile ve Aile İş̧ Çatışmalarının Çalışanların İş ve Yaşam Tatminleri Üzerindeki Etkisi. [The effects of work-family conflict and family-work conflict on employee's job and life satisfaction in organizations.] Erciyes Üniversitesi İktisadi ve İdari Bilimler Fakültesi Dergisi, 33, 69-99.

Özer M., \& Karabulut, Ö.Ö. (2003) Yaşlılarda yaşam doyumu. [Satisfaction of life in elderly individuals.] Geriatri, 6(2), $72-74$.

Özmete, E., \& Eker, I. (2012). İş-aile yaşamı çatışması ve roller: kamu sektörü örneğinde bir değerlendirme. [Work-Family Conflict and Roles: Assessment of the Public Sector.] Çalışma İlişkileri Dergisi, 3(2), 1-23.

Panatik, S. A. B., Badri, S. K. Z., Rajab, A., Rahman, H. A., \& Shah, I. M. (2011). The impact of work family conflict on psychological well-being among school teachers in Malaysia. Procedia-Social and Behavioral Sciences, 29, 1500-1507. http://dx.doi.org/10.1016/j.sbspro.2011.11.390

Perrone, K. M., Webb, L. K., \& Jackson, Z. V. (2007). Relatonship between parental attachment, work and family roles, and life satisfaction. The Career Development Quarterly, 55(3), 237-248. http://dx.doi.org/10.1002/j.2161-0045.2007.tb00080.x

Skaalvik, E. M., \& Skaalvik, S. (2007). Dimension of teacher self-efficacy and relations wiht strain factors, perceived collective teacher efficacy, and teacher burnout. Journal of Educational Psychology, 99(3), 611-625. http://dx.doi.org/10.1037/0022-0663.99.3.611

Telef, B. B. (2011). The study of teachers' self-efficacy, job satisfaction, life satisfaction and burnout. Elementary Education Online, 10(1), 91-108.

Trachtenberg, V. J., Anderson, A. S., \& Sabatelli, M. R. (2009). Work-home conflict and domestic violence: A test of conceptual model. Journal of Family Violence, 24, 471-483. http://dx.doi.org/10.1007/s10896-009-9246-3 
Turunç, Ö., \& Eruş, A. (2010) İş-aile yaşam çatışmasının iş tatmini ve örgütsel bağlllık üzerine etkileri: iş stresinin aracılık rolü. [Work- Family Conflict Effects of Job Satisfaction and Organizational Commitment.] Selçuk Üniversitesi Sosyal ve Ekonomik Araştırmalar Dergisi, (19),415- 440.

Uyargil, C. (1983). Kişinin genel yaşam tatmininde işinin önemi. [The importance of job satisfaction in the general life of the people.] İstanbul Üniversitesi Eğitim Fakültesi Dergisi, 2, 86-90.

Van Houtte, M. (2006). Tracking and teacher satisfaction: Role of study culture and trust. Journal of Educational Research, 99(4), 247-254. http://dx.doi.org/ 10.3200/JOER.99.4.247-256

Yıldırım, F. (1996). Banka çalışanlarında iş doyumu ve algılanan rol çatışması ile tükenmişlik arasındaki ilişki. [The Relationship of job satisfaction and role conflict to burnout in banking personnel.] Unpublished master thesis, Ankara: Hacettepe Üniversitesi, Sosyal Bilimler Enstitüsü.

Yılmaz, E., \& Şahin, M. (2009). A study into life satisfaction levels of the teachers working at primary education in terms of some variables. E-Journal of New World Sciences Academy, 4(4). www. newwsa. com.

\section{$(\boldsymbol{c c )}) \mathbf{E Y}$}

This work is licensed under a Creative Commons Attribution 3.0 License. 